\title{
Incitement: A Study in Language Crime
}

\author{
Joseph Jaconelli ${ }^{1}$ iD
}

Published online: 19 July 2017

(C) The Author(s) 2017. This article is an open access publication

\begin{abstract}
A person incurs inchoate criminal liability when he incites another person or other persons to commit a crime. The most salient characteristic of incitement, in comparison with the other forms of inchoate crime, is the existence of a communication that is made with a view to persuading the addressee(s) to commit an offence. This article explores the question of why incitement should incur criminal liability, and the nature of such liability. It also identifies its distinctive features. The principal focus here is on ambiguity in the putative words of incitement and on questions of gauging whether the words have had any effect on the actions of the addressee(s). It covers both the standard criminal offences and conduct which, arguably, should not be regulated by the criminal law, thereby raising issues of freedom of speech. Legal issues are set in the context of the common law generally, while drawing (for the most part) on English law in matters of detail.
\end{abstract}

Keywords Advocacy · Craig and Bentley case · Inchoate crime · Incitement · Freedom of speech · Genocide · Mill On Liberty · Terrorism

\section{The General Features of Incitement}

Of the three forms in which inchoate crime may exist-attempt, conspiracy, and incitement - it is attempt that has received by far the most discussion, followed at some distance by conspiracy. ${ }^{1}$ Yet incitement, too, poses a number of problems, both theoretical and practical, that merit an examination that goes beyond the standard measure of treatment in the criminal law texts. The present article, in contrast to these accounts, will concentrate on the pivotal role played by language as the means of effecting the communication (whether

\footnotetext{
${ }^{1}$ See especially R.A. Duff, Criminal Attempts (Oxford 1996) and I. Dennis, "The Rationale of Criminal Conspiracy" (1977) 93 L.Q.R. 39.
}

Joseph Jaconelli

joseph.jaconelli@manchester.ac.uk

1 Law School, University of Manchester, Manchester M13 9PL, UK 
in written or oral form) which is at the core of the act of inciting criminal conduct. This approach, in addition to raising a number of considerations that are peculiar to the use of language in the criminal law, engages the tension that exists between some areas (at least) of incitement and issues of the protection of freedom of speech. It should be noted, at the outset, that "language" and "speech" will not be used interchangeably in this paper. The former will be used to designate any form of linguistic communication whatsoever, while the latter will be limited to those communications that can be regarded as possessing a modicum of social value so as to gain special protection, whether under any applicable human rights document or under the common law.

The essence of the law of incitement is that a person (the "inciter") urges another person or persons (the "incitee(s)") to commit a criminal offence. A long-standing form of liability at common law, it has been restated in English law in Part 2 of the Serious Crime Act 2007. ${ }^{2}$ This encompasses two different but cognate actions: "encouraging" the commission of a crime, and "assisting" in its perpetration. As such, it juxtaposes the ground previously occupied by the common law of incitement and that of accessory liability. "Incitement," as the older and more familiar word, will continue to be used here in preference to "encouragement." Accessory liability or "assisting" is relevant to the present paper only insofar as it sheds some comparative light on incitement.

The bare message of incitement may be reinforced in various ways; for example, by the inciter adducing reasons (ranging from practical to moral considerations) as to why the incitee should commit the crime. Incitement is also distinct from, but can overlap with, situations where the inciter brings other influences to bear on him, whether by way of inducement (a bribe) or coercion (in the form of threats, which may amount to duress in law).

Some general points about the structure and scope of incitement must first be explored.

\subsection{Words and Predicate Crime}

There are, irreducibly, two elements in the subject: the words of incitement themselves; and what will be described as the "predicate offence."

The latter consists of the criminal offence(s) that the incitee is being urged to commit, irrespective of whether he proceeds to commit it. Sometimes the nature of the predicate offence will be abundantly clear from the words used by the inciter. More often, however, the inciter's language will be ambiguous. This should not be surprising, for the people who are tried by the criminal courts do not characteristically choose their words with great care. The difficulty in identifying the predicate crime is illustrated by the statutory incitement provision applicable to terrorist offences. The Terrorism Act 2006, section 1, penalises any statement that is "a direct or indirect encouragement or other inducement to [the addressees] to the commission, preparation or instigation of acts of terrorism...." There is no completed crime of performing an "act of terrorism": there is only a range of crimes that can be committed either in a terrorist mode or in a non-terrorist mode.

As regards the first element, a number of terms have been used in the law to represent the idea of a person seeking to direct the actions of another towards criminal conduct: examples include "incite," "counsel," "encourage," "solicit," "promote," and "induce." The Offences against the Person Act 1861, section 4, uses the word "solicit" but for good measure adds "encourage" and "persuade" - an excess of terminology that is understandable in view of the gravity of murder, the predicate crime in this provision. There is no reason to believe that the meaning of any one of these verbs differs significantly from

\footnotetext{
${ }^{2}$ Serious Crime Act 2007, s. 59.
} 
the meaning of any other that is in common use in this context-save in one regard. Some verbs carry the nuance that the words in question succeed in their conduct-shaping objective. Where such verbs are deployed, they would appear to leave unregulated by law the situation where the words failed in their purpose, with a consequent need to make express provision for that contingency. ${ }^{3}$

Remarkably, the same idea of addressing others with a view to altering their conduct is to be found in provisions where the predicate action is not even a legal wrong. These are perforce statutory since the common law of incitement attaches only to substantive crimes. An early instance, section 3(2) of the Aliens (Restriction) Amendment Act 1919, penalised any alien who "promotes or attempts to promote industrial unrest," its date revealing it as a clumsy attempt to halt the spread of the Russian Revolution. More recently, section 28 of the Local Government Act 1988 forbade local authorities to "intentionally promote homosexuality" in schools, the section being enforceable by way of administrative procedures. ${ }^{4}$ The same point can be made of both provisions: there is not, and never was, a crime of "industrial unrest" or of "homosexuality." Alternatively, incitement may encompass a range of predicate conduct, only some forms of which qualify as criminal offences. The former common law offence of sedition illustrates the point. The classic definition of the crime stated that it was "to incite any person to commit any crime in disturbance of the peace, or to raise discontent or disaffection amongst His Majesty's subjects, or to promote feelings of ill-will and hostility between different classes of such subjects." 5 The first limb of this definition was firmly rooted in substantive criminal offences; the second part encompassed a variety of conduct, some forms of which were unregulated by law and others of which have now been subsumed in the specific statutory offences of incitement of racial or religious hatred.

In incitement, as in attempted crime, there are delicate questions of judgement as to exactly at what point the law should intervene. In the interest of refining that point, a distinction has sometimes been drawn between incitement that is "direct" and incitement that is "indirect" so that the ambit of the relevant law is expanded, or (alternatively) reduced, by reference to its usual scope. The same distinction is also found in the context of other words of instigation. A pre-eminent example is section 1 of the Terrorism Act 2006, which aims to strike at the cultivation of potential recruits to terrorist causes. ${ }^{6}$ Reflecting the gravity of the predicate conduct, it is drafted so as to encompass "indirect" as well as "direct" encouragement to commit acts of terrorism. Presumably it is in the latter sense that "encouragement" (or "incitement" or other such word) is meant when it is used without further elaboration, since "indirect" encouragement would encompass a fortiori encouragement which is direct. In marked contrast, the distinction may be drawn in order to make it clear that the provision in question is confined to "direct" incitement only. The Genocide Convention of 1948, Article 3(c), in this way, is limited to the "direct and public incitement to commit genocide." 7

\footnotetext{
3 In this way, the Police Act 1964, s. 53(1), penalises a person who "induces" a police officer to commit a disciplinary offence, and is supplemented by the additional phrases, "or attempts to induce" and "does any act calculated to induce," such an offence.

4 It was repealed by the Local Government Act 2003, s. 122.

5 This definition, given by Stephen, was adopted in the Law Commission Working Paper No. 72, Codification of the Criminal Law, Sedition and Allied Offences, p. 42.

${ }^{6}$ It has since been reinforced by the Counter-Terrorism and Security Act 2015, Part V, with a battery of provisions with the aim of preventing people from "being drawn into terrorism."

7 The same formula is used in the Rome Statute of the International Criminal Court 2002, Article 25(3)(e).
} 
The details of what amounts to indirect, as opposed to direct, incitement (or encouragement) will vary as between different legal regimes that employ that distinction, or different provisions within the same regime. But, generally, it may be said that direct incitement is explicitly to urge another person to commit the predicate offence. Indirect incitement is more circumspect, consisting of such forms as to state that committing a particular crime is morally justified or to be applauded, the message possibly being communicated even by the use of metaphor. These instances may be inferred as plausible extensions of the particular example of indirect incitement given in section 1(3) of the Terrorism Act 2006; namely, to "glorify" the commission of any act of terrorism. No matter how morally reprehensible it may be to applaud (still less, glorify) criminal acts that took place in the past, to impose liability for these actions is strikingly out of line with the general structure of the criminal law. The thread that runs through inchoate liability, in all its forms, is the prevention or punishment of present or future conduct. Yet it is possible to penalise the glorification of past crimes, without at the same time detracting from the general structure of the criminal law, by characterising it as a contributory factor to encouraging the commission of further crimes of the same type. ${ }^{8}$

\subsection{Primary or Secondary Liability}

If the decision has been taken to criminalise a particular type of conduct, there is abundant reason for imposing liability on its inchoate forms also. It has been said, in the context of attempt, that a law that did not do so "would speak with a strange moral voice." 9 The same is broadly true of incitement. ${ }^{10}$ Once a system of criminal jurisprudence has taken the step of penalising the uttering of words of incitement, the most significant decision that it must then take is as to how the words of incitement are to relate to the predicate crime. There are two principal approaches.

The first is the position taken historically by English law: that the (inchoate) crime is committed immediately the words of instigation are uttered, and irrespective of the nature of the response (if any) that the words arouse in the incitee(s). Of course, the suggestion that the latter should commit the crime in question may be made flippantly, or may be uttered in circumstances where there is not the least likelihood of evoking a compliant response. Herein lies the significance of the Serious Crime Act 2007, which contains the alternative requirements that the inciter "intends to encourage...its commission" (section 44) or that "he believes-(1) that the offence will be committed;" and (2) "that his act will encourage...its commission" (section 45). This is in addition to the element, common

\footnotetext{
8 A case in point is $R v$. Antonelli and Barberi (1906) J.P. 4, the prosecution of the distributors of an Italian language newspaper published in London. On the fifth anniversary of the murder of the King of Italy, it carried an article in praise of the assassin. On appeal against conviction Phillimore J. ruled: "The question is-Does it, by the praise of [the assassin] incite anyone to murder Emmanuel III [the then-King of Italy] or any other sovereign of Europe?" (ibid., at p. 6). A striking difference is that s. 1(3) penalises the glorification of any act of terrorism per se, while in this case the matter was left to the jury as to whether it amounted to incitement.

9 Duff, Criminal Attempts, p. 134. However, see G. Yaffe, Attempts in the Philosophy of Action and the Criminal Law (Oxford 2010), especially chapter 1, for an exposition and critique of what Yaffe calls the "Transfer Principle" - that is, the principle that "the legitimacy of criminalization transfers from completion to attempt" (p. 21). An examination of whether a similar principle could be applicable to incitement liability is beyond the scope of the present article.

${ }^{10}$ See, further, S. Leader, "Free Speech and the Advocacy of Illegal Action in Law and Political Theory" (1982) 82 Columbia Law Review 412.
} 
to both sections, that the accused "does an act capable of encouraging...the commission of an offence." 11

The second approach requires that the incitee act on the words of incitement by committing the predicate crime or (at least) attempting to do so. That is, the words of the inciter have caused, or in some sense contributed to, his conduct. This hinges on the commission of the predicate crime by the incitee as the essence of the mischief with which the law of incitement is concerned.

The sequence of criminal conduct that is put in motion may extend beyond the immediate predicate offence. There are provisions that, reflecting this point, create an enlarged net of liability. Under section 22(2) of the Canadian Criminal Code 1985, in this way, any person who "counsels" another to commit an offence "is a party to every offence that the other commits in consequence of the counselling that the person who counselled knew or ought to have known was likely to be committed in consequence of the counselling." Yet, as this provision intimates, there must be some limitations if the words of incitement are not to be held responsible for the opening of a Pandora's Box of criminality ranging, in extent and type, far beyond the immediate predicate crime. ${ }^{12}$

There are some possible variations on the themes of the two principal approaches. One is grounded as a matter of substantive law in the first of these, but tempered by a prosecutorial policy whereby proceedings are to be brought only in circumstances where the completed crime is perpetrated by an incitee. Another, a significantly qualified variation on the second approach, was put forward by John Stuart Mill. "Instigation," he submitted, could properly be made punishable only if an "overt act has followed" ... "and at least a probable connection can be established between the act and the instigation." 13 Therefore, instigation alone, without any attendant consequences, should not be punishable. Equally, the presence of such consequences should not suffice to ground liability in the absence of a "probable connection" between the two. Although outlined by Mill in the specific context of tyrannicide, this could be made applicable to any offence in the criminal calendar. Indeed, the U.S. Supreme Court, without seemingly being aware of the debt, propounded a remarkably similar test for the constitutionally permissible extent of the law of incitement in Brandenburg v. Ohio: that the First Amendment did not permit a state to forbid "advocacy of the use of force or of law violation except where such advocacy is directed to inciting or producing imminent lawless action and is likely to incite or produce such action." 14

So far as the two principal approaches are concerned, there are difficulties with each of them. If the message of incitement fails to evoke a criminal response, no harm of the sort of which the law should take cognisance (it could be argued) will have been done. However, if the incitee positively responds to the call to crime, a different issue is presented-one that is clearly expressed by Joel Feinberg:

It might well be asked how one person-the inciter-can be held criminally responsible for the free and deliberate actions of another person-the one who is

\footnotetext{
11 Serious Crime Act 2007, ss. 44(1) and 45(1).

12 It is possible that the Serious Crime Act 2007, s. 49(2), may serve the same function in dealing with the position where the action of the accused is "capable of encouraging...the commission of a number of offences." In the absence of authority, it is unclear whether this refers to a series of offences in sequence, or a range of alternative offences in the first place, or indeed both these situations.

13 J.S. Mill, On Liberty (Penguin Classics ed. London 1985), p. 76n.

14395 U.S. 444 (1969). A noteworthy point of difference is that Mill requires a connected act to follow, not (as here) a combination of the intent with which the words were spoken and their likely consequences.
} 
incited by his words. ...for the deliberate, thoughtful, unforced, and undeceived acceptance of the advice of another person is without question itself a voluntary act. $^{15}$

The short response to this point is that the inciter is judged liable notwithstanding the fact that the incitee does not proceed to commit the substantive crime, nor was there any prospect of his doing so. The inciter is being held criminally responsible for his own actions, not those of the incitee. Or, to view the matter from a slightly different angle, the action of inciting crime is a wrong in itself (a "malum in se," as it is sometimes termed). The inciter's responsibility may thus be described as "primary" in nature. If it were contingent on the nature of the response provoked by his words in the incitee-a matter that could simply be a matter of chance-it could be aptly described as being one of "secondary" liability. ${ }^{16}$ It is worth noting, however, that one of Feinberg's conditions is that the incitee's reaction is "thoughtful" — a condition that is absent when the incitee's response is given in the heat of the moment.

Thomas Scanlon presents a similar viewpoint to that of Feinberg, focusing instead on the situations where the inciter could be held responsible for any crime committed by the incitee - or, more crucially, the situations where he could be held to be criminally liable in his own right. Those circumstances are where the incitee is a child, or so weak-minded as to be legally incompetent, or if the words uttered by the inciter were addressed in the form of an order to a subordinate. ${ }^{17}$ The theme common to all these situations is the disparity of status as between the parties.

Finally, a system of criminal law that fully embraced the primary nature of incitement liability would not classify differently a situation where the predicate crime was committed by the incitee and one where he remained unmoved by the words of incitement. Such unremitting logic, however, was lost in the development of English law. A bifurcated position emerged whereby, if the incitee committed the crime in question, the inciter would be an accessory before the fact; if he did not, the situation remained categorised as one of "incitement."

\subsection{The Primary Character of Liability Exemplified}

The primary nature of incitement liability can be exemplified in several different ways, both actual and hypothetical. This can be done by examining the ways in which the words of the inciter may interact with the response of the incitee.

Let us first take the situation where the incitee does not respond to the words of the inciter. As already noted, it is immaterial to the liability of the inciter that the crime that is instigated is not carried out. As a matter of English law, this has now been made explicit, both generally ${ }^{18}$ and in the specific context of terrorism. ${ }^{19}$ It is surprising that it was felt necessary to make this clear. There appears to have been no need to spell out the point that

\footnotetext{
15 J. Feinberg, "Limits to the Free Expression of Opinion" in J. Feinberg and J. Coleman, Philosophy of Law (7th ed., London 2004), 379, at p. 390.

16 Nevertheless, the seriousness of an act of incitement is generally considered to be determined, in some unspecified way, by the gravity of the crime that is incited. This link, it is submitted, does not detract from the essentially primary nature of incitement liability.

17 T. Scanlon, "A Theory of Freedom of Expression" (1972) 1 Philosophy and Public Affairs 204: reprinted as T. Scanlon, The Difficulty of Tolerance: Essays in Political Philosophy (Cambridge 2003), chapter 1.

18 Serious Crime Act 2007, s. 49(1).

19 Terrorism Act 2006, s. 1(5)(b).
} 
an unsuccessful attempt to commit a crime, or an attempt that is abandoned, nevertheless attracts criminal liability. The same applies to a planned criminal conspiracy that is not in fact executed. These are all examples of inchoate crime; and it is a reasonable assumption that the term "inchoate" signifies that the completed crime is not committed-by anyone. That Parliament was required to state what would appear to be obvious may stem from a peculiarity of incitement when compared with attempt and conspiracy. Once the words of incitement are uttered, whether the full crime is committed is outside the control of the inciter and depends on the volition of the incitee.

Historically, this fundamental point in the scope of the law of incitement was decided in Higgins, ${ }^{20}$ where the charge against the accused was that he did "solicit and incite" an employee to steal a quantity of material from his employer. The main point in the case was the question as to whether "some act should be laid to have been done in pursuance of the incitement" - a matter of some importance since the indictment did not specify that the employee did steal the goods in question. The court confessed to being unaware of any case where such further specification had been necessary. "[T]he gist of the offence," it emphasised, "is the incitement" - a pronouncement that appears to be contradicted later in the judgement in describing as "an attempt to incite" the situation where there is no criminal response forthcoming from the incitee. ${ }^{21}$

This suffices to establish the primary nature of incitement liability. It could be reinforced by a consideration of the converse situation: one in which the incitee does proceed to commit the predicate crime. Let us assume that it could be established that the incitee would still have done so, even in the absence of the inciter's words of encouragement. The moral significance of this assumption lies in its establishing that the words uttered by the inciter did not contribute to the sum total of criminal conduct (in the sense of the perpetration of a completed crime that would not otherwise have occurred). Should the inciter, consequently, be exempt from liability? Certainly, if such an argument were to be raised it might be difficult to convince a court of such a counter-factual sequence of events. However, the requirement to pursue such a hypothetical line of investigation is not uncommon in the law, as the following examples illustrate.

Take the situation where a buyer purchases defective goods from a seller who has misrepresented their quality to him. The contractual redress that the buyer might have had will be denied to him if the seller can establish that the buyer would still have entered into the contract regardless of whether the misrepresentation had been made. This situation is analogous to the incitement scenario just outlined since the seller is put to establishing a hypothetical course of events. However, it might be replied, this position differs in a significant respect from that scenario since the outcome of such speculation has far more serious consequences where it is criminal liability that is at stake.

Yet, even in the criminal law, the requirement to pursue such a speculative line of investigation is not unknown. The offence of insider dealing illustrates the point. Typically the misconduct takes the form of a company director who has access to confidential, pricesensitive information (the "tipper") disclosing the information to another person (the "tippee") so that the latter is able to speculate profitably in the company's shares. The law makes explicit what is implicit in the criminalising of such conduct: that a person is not

20 (1801) 2 East 5; 103 E.R. 269.

21 Nevertheless, the ruling appears to be consistent with a much earlier, briefly reported, case: Bacon (1664) 1 Lev. 146; 83 E.R. 341. The accused had offered a sum of money to a person to carry out a murder. In rejecting his appeal against conviction, the court stated simply: "anciently the will was taken for the deed in matters of felony.". 
guilty of the crime by reason of "encouraging" the tippee to deal in the relevant securities if he shows that the tippee "would have done what he did even if he had not had the information" 22

Consequently, it may be assumed from these examples that it is not the existence of insuperable practical difficulties that forms the obstacle to the adoption of counter-factual speculation in this area.

Aside from practical issues, a further test of primary liability may be identified in the very structure of the law. Does incitement recognise a defence of "voluntary abandonment" similar to the doctrine that goes by that name in the law of attempt? This holds that a person who sets out to commit a crime, and has proceeded far enough along that path to be guilty of an attempt, avoids liability if he then abandons his criminal design. ${ }^{23}$ Some conditions attach to the defence; in particular, that it must represent a genuine change of heart. In the same way, would a person who instigates another to commit a crime avoid liability for incitement if, before the incitee could act on the words, he communicates to the latter a message retracting his earlier encouragement? Furthermore, should that suffice for an abandonment, or must the message be effective in dissuading the incitee ? $^{24}$

As with attempt, there are arguments of principle in favour of both points of view. By the act of repenting, the inciter has not evinced "dangerousness of character" and consequently, it could be said, should not be subjected to criminal process. On the other hand, an act of incitement is committed just as soon as the words of encouragement have been expressed and irrespective of the reaction that they elicit. There is no clear authority on the point as regards incitement. It is noteworthy that Sir James Stephen believed that, by countermanding, the inciter avoided liability for being an accessory before the fact if the message were communicated to the incitee before the completed crime could be committed. $^{25}$

A fundamental characteristic of incitement, as will be noted, is that it readily admits of the possibility of multiple incitees. The consequence for the present purpose is that a complete revocation of the words of instigation may prove difficult, if not impossible. However, this could be taken as going to the issue of whether-in those circumstances only-an effective abandonment is truly feasible. Above all, whether the completed crime is committed or not is outside the control of the inciter. Duff's words, written in the context of attempt, are especially relevant here: "...by completing the attempt he did what would, for all he knew, put it beyond his power to prevent the crime's completion."26

\subsection{The Mens Rea of Incitement}

Some important points on incitement were uncertain until the enactment of the Serious Crime Act 2007. A classic text had disposed briefly of the mental element: "Intention or, at least, recklessness is needful." ${ }^{27}$ Likewise, the Supreme Court of Canada in $R$ v. Hamil$\operatorname{ton}^{28}$ stated that mens rea required an accompanying "intent or conscious disregard of

\footnotetext{
22 Criminal Justice Act 1993, s. 53(1)(c) and s. 53(2)(c).

23 Duff, Criminal Attempts, at pp. 66-75.

24 The former would fit with the idea of incitement as imposing primary liability. I am grateful to Antony Duff for making this point to me.

25 J. Stephen, A Digest of the Criminal Law (Indictable Offences) (9th ed., by Sturge: London 1950), p. 20.

26 Duff, Criminal Attempts, at p. 396.

27 G. Williams, Criminal Law: The General Part (2nd ed., London 1961), p. 611.

28 (2005) 255 D. L. R. (4th) 283.
} 
[emphasis added] the substantial and unjustified risk inherent in the counselling." ${ }^{29}$ Recent writings on English law have favoured a stricter approach. Victor Tadros has emphasised the point that "it is fundamental to incitement that one identifies in some way with the conduct of the incitee. ${ }^{30}$ The Law Commission report that led to the enactment of the Serious Crime Act 2007 appears to have been persuaded by Andrew Ashworth's view that, in the realm of inchoate offences, mere recklessness should not suffice. ${ }^{31}$ The stricter approach, it could be added, is especially appropriate in the realm of language crime with its attendant possibility of interpretations being placed on the crucial words that differ from the speaker's intended meaning. As already noted, the 2007 Act provides that the mental element is either that the accused intends to encourage its commission (section 44) or a combined belief that it will be committed and that his act will provide encouragement to that end (section 45). The former needs to be read against the principle that, when a criminal statute uses the term "intention," nothing less than that (recklessness, for instance) will suffice.

There remains here a significant element of uncertainty that will be explored in Sect. 3, below.

\subsection{The Distinctive Aspects of Incitement Liability}

Even a brief exposition of the fundamentals of incitement suffices to suggest that it possesses several distinctive features. These will be recounted here and examined at greater length in the rest of this article.

First, the communication that constitutes the action of incitement might be made on a one-to-one basis. At the other extreme, it could be made to a multiplicity of individuals (in newspapers and other media outlets, or the internet). Indeed, the perpetration of mass crimes will typically require structures, whether of communication or of command, within which co-ordinated conduct is rendered possible. Recent history has shown this, tragically, to be true of genocide. ${ }^{32}$

Secondly, the prevalence of multi-sided communications means that incitement is more likely than other facets of the criminal law to raise cross-border issues. This is a factor that is explicitly recognised in section 4 of the Offences against the Person Act 1861 in stating that the inciter is liable in proposing "to any person" that he commit murder notwithstanding the fact that the ultimate victim may not be in the "Queen's dominions." This is reflected more recently in the English draft Criminal Code (1989), clause 47 (4), which stipulates that a person could be convicted of incitement "although the identity of the person incited is unknown." The victim or victims of any consummated crimes that ensue from the communication may, likewise, be unknown and be located beyond national borders. Consequently, incitement is potentially the most far-reaching, yet uncertain, form of inchoate crime, since it may prove impossible to ascertain the number, location, or identity of the incitee(s) and of any possible victims. There was an unsuccessful attempt to

\footnotetext{
${ }^{29}$ Ibid., at para. [29].

30 V. Tadros, "The System of the Criminal Law" (2002) 22 Legal Studies 448, at p. 454.

31 Law Commission, Inchoate Liability for Assisting and Encouraging Crime (Cm 6878, 2006), at para. 5.19 .

32 Most notably, several of the prosecutions brought in the aftermath of the Rwanda genocide of 1994 were based on charges of incitement: see L. May, Genocide: A Normative Account (Cambridge 2010), chapter 10 ("Incitement to Genocide and the Rwanda Media case").
} 
limit the scope of section 4 in $R v$. Most, ${ }^{33}$ which concerned a German language newspaper, Freiheit, published in London. The offending article applauded the recent murder of the Emperor of Russia [a reference to Czar Alexander II] as "an example to revolutionists throughout the world." As such, it was a manifestation of the regicidal mood spreading through Europe in the second half of the nineteenth century. The defendant argued that "any person" meant "some definite person." Denman J. rejected the submission: "I think the circulation to the world, to multitudes of persons wholly undefined, and to whom it would come, would be sufficient." ${ }^{34}$ In so ruling, he greatly enhanced the possible scope of section 4.

Thirdly, the communication that is at the core of incitement could be ambiguous, thereby giving rise to problems in the construction of the language used. ${ }^{35}$

Fourthly, even where there is a settled core of meaning in the message, it may evoke different reactions from different people. Some may be persuaded to commit the predicate crime, while others might be repelled even by the suggestion that they should do so. ${ }^{36}$

Fifthly, outside the settled core of the criminal law, in areas where the imposition of liability may be the subject of public debate, the dissemination of the view that particular actions do not merit such liability may well be taken as expressing the opinion that there is a moral right to break that law pending its reform. This, in turn, creates a conflict between the law of incitement and freedom of speech. ${ }^{37}$

\section{The Interpretation of Language}

The work of lawyers is inextricably involved with the analysis of language, whether in interpreting the sources of law itself (as in statutory construction) or in scrutinising the terms of private legal instruments (for example, contracts). These will have benefitted from professional drafting, invariably in the former case and usually in the latter. That point apart, the very fact of their being in written form will tend towards greater care in their composition. The opposite is true of oral communication, especially words of incitement, uttered without the benefit of legal advice, and typically blurted out without pause for reflection. Attributing meaning to them is, therefore, all the more difficult. ${ }^{38}$ For this purpose, our discussion will be divided between issues of explicit incitement and oblique incitement. "Explicit incitement" describes the situation where the words can plausibly be interpreted as an instigation to commit a crime. This term will also be used of two sets of problematic circumstances under this heading: where the exact nature of the crime is not apparent from the words used; and where the words, on an alternative interpretation, could equally be construed as not amounting to a message of incitement at all. "Oblique incitement," by contrast, is not literally a call to commit crime, but the foreseeable (and

\footnotetext{
33 (1881) 7 Q.B.D. 244.

34 (1881) 7 Q.B.D. 244, at p. 257.

35 See further Sect. 2, below.

36 See further Sect. 3, below.

37 See further Sect. 4, below.

${ }^{38}$ For an unusual instance of a case that involved liability for, and the interpretation of, spoken words, see $R$ v. Malik [1968] 1 All E.R. 582. The defendant argued that the words that he was charged with having spoken had a different meaning to him, as a West Indian, than to someone raised in Britain: see at p. 583B. The response of the court is at p. 584 .
} 
possibly intended) consequence of the uttering of the words is the perpetration of some criminal offence by the person(s) being addressed.

\subsection{Explicit Incitement}

Instances of explicit incitement, for most purposes, are easy to identity. Consequently the focus here will be on the problematic situations mentioned above. Two episodes, separated by nearly 800 years, respectively illustrate the difficulties.

The first occurred in 1170, arising out of the acrimonious disagreements between King Henry II and Thomas Becket over the respective powers of church and state. The King, in a fit of exasperation, called out (according to legend): "Will no one rid me of this turbulent priest?" Four knights then went to Canterbury Cathedral, where they murdered Becket. That the King could be put on trial for instigating murder was not, of course, in the realm of possibility. The actions of the knights show clearly that they interpreted his words as a call to murder Becket. But that is very different from the question of his intention, as to which there were two points of uncertainty. Were his words intended to be a call to kill Beckett, as opposed to removing his interference in other ways? Indeed, would it even be intelligible to speak in terms of the King having had a clear intention as to the exact form in which he wished to be rid of Becket?

The second episode, the notorious case of Craig and Bentley in 1952, provides an even more striking illustration of the problems inherent in language as the central element in incitement. ${ }^{39}$ It is necessary to recall the facts. The accused were very different in character. Christopher Craig had marked criminal propensities, in particular an obsession with guns. Derek Bentley had a record for petty theft, largely attributable to the fact that he suffered from learning difficulties and was easily led astray. One evening, they decided on an impulse to burgle a warehouse. Craig, to Bentley's knowledge, was carrying a gun. They were seen behaving suspiciously by neighbours, who raised the alarm, and the building was surrounded by the police. The final stages of the tragedy unfolded on the long, flat roof of the warehouse. Bentley was soon arrested by the first officer to reach the roof, Detective-Constable Fairfax. Craig held Fairfax at bay by brandishing his weapon. Bentley broke free, calling out: "Let him have it, Chris." Craig then fired his gun, wounding Fairfax in the shoulder. Craig went on to shoot repeatedly at random, killing a policeman, P.C. Miles, who had only just arrived on the roof top. Both accused were found guilty of murder: Craig for having fired the fatal shot, and Bentley for having incited him. Only Bentley was hanged since Craig, although more culpable, was below the age (18 years) at which persons could be subjected to capital punishment. No case could point up more vividly the critical role that can be played by incitement, Bentley being executed for having uttered five words. ${ }^{40}$

The case also furnishes practical perspectives on two points that were mentioned in Sect. 1. It may reasonably be surmised that the murder and wounding of the police officers would have occurred regardless of whether Bentley had shouted the critical words. Craig was surrounded and in a panic, gun at the ready, and inflamed with feelings of hatred

\footnotetext{
39 The transcript of the trial is contained in the Notable British Trials series: H. Montgomery Hyde (ed.), The Trial of Christopher Craig and Derek William Bentley (London 1954).

40 There was another important point of law in the case. Under the doctrine of common design, if both accused had embarked on their enterprise with the intention of offering violence, they would both be held liable for any force that might be used by only one of them. The doctrine would appear to have sufficed to secure Bentley's conviction. However, it was thought to be no longer applicable as soon as Bentley, as the other participant, was arrested.
} 
towards the police. ${ }^{41}$ The case was also very different from Scanlon's depiction of one of the types of situation where incitement liability may properly be imposed: that is, where the incitee is under the controlling influence of the inciter. Craig, far from being under the influence of Bentley, was the prime mover in the enterprise. Of the two, it was Bentley who could properly be described as "weak-minded." This is in addition to the fact that, being under arrest at the time, he was in no position to assert any authority that he might have possessed over Craig.

It is the ambiguity of Bentley's words that is our concern here. ${ }^{42}$ It would be difficult to conceive of a situation where there was a wider gulf between the competing meanings of the same words. Did "Let him have it" possess a malevolent meaning ("Shoot the policeman"), or one that was benign ("Surrender your gun to him")? Before approaching that question, it is necessary to note other aspects of those words.

If the nature of the exhortation was ambiguous, there was no uncertainty as to the person to whom the words were referring. Even on the malevolent interpretation, they will have amounted to a call to shoot Detective-Constable Fairfax only. Nonetheless, the case for the prosecution, as presented in its opening speech, depended on an interpretation to the effect "that incitement...covered the whole of the shooting thereafter." 43 This is a very strained construction. It is also one that would seem to be precluded by an illustration given in the edition of Stephen's work on the criminal law that was contemporary with the murder: "A instigates $\mathrm{B}$ to murder $\mathrm{C}, \mathrm{B}$ murders D; A is not accessory before the fact to the murder of D." ${ }^{44}$ Yet such an approach could conceivably fit with the tenor of at least one statement of incitement liability. As already noted, under section 22(2) of the Canadian Criminal Code, there is scope for imposing liability on the inciter for crimes committed by the incitee that go beyond the original predicate crime that the inciter could foresee as likely to ensue from the initial act of counselling. Whether such extended liability could properly be imposed at common law, without the explicit warrant of a provision such as section 22(2), is doubtful. If it could not, the only possible basis for the imposition of liability for incitement would be that Bentley's words were to be construed broadly as a call to resist arrest, from whatever quarter, by potentially lethal force.

Some accounts of the case, furthermore, attach importance to the lapse of time between the uttering of the words and the shooting of P.C. Miles, a period estimated as being at least $15 \mathrm{~min}$. The question has been posed: “.... are we to assume that if Craig had escaped from the roof, and if Miles had caught up with him and been shot a day, a week, a year later, then Bentley would still be guilty of murder?" 45 Presumably the point behind the query is that, the longer the gap between the uttering of the words of incitement and the perpetration of the predicate crime, the greater the scope for arguing for the intrusion of other causal factors contributing to the latter. The answer, however, must unquestionably be in the affirmative. The fallacy behind the question lies in its failure to recognise that liability for

\footnotetext{
41 The reason was that the police had recently secured the conviction for violent crime of Craig's brother.

42 There is a further, less well known, ambiguity in the exchanges on the roof. When the police were removing Bentley from the crime scene, after the murder but while Craig was still at large, Bentley shouted: "Look out, Chris; they're taking me down." There was some inconclusive discussion at the trial as to whether this was a further incitement to Craig to continue shooting, or whether it was a plea to him to stop in case he, Bentley, was caught in the cross-fire. See The Trial of Christopher Craig and Derek William Bentley, at pp. 43, 191-192, and 204.

43 The Trial of Christopher Craig and Derek William Bentley, at p. 41.

44 Stephen, A Digest of the Criminal Law at p. 21.

45 D. Yallop, To Encourage the Others (London 1971), p. 151.
} 
incitement is primary in nature: hence, these other considerations are irrelevant. Once Bentley had uttered the words of incitement, he was liable irrespective of whether anyone was killed in consequence, or whether a different person was killed from the person envisaged at the time of their uttering, or whether any killing that did occur took place after a considerable lapse of time. ${ }^{46}$

There also remains some considerable doubt as to whether Bentley shouted the critical words. He testified that he had not done so, and Craig denied having heard anything of the sort. Bentley was condemned on the basis of the evidence of three police officers that they had heard the words. ${ }^{47}$ But their testimony could go only to the question of whether the words had been uttered. It had little bearing on the issue of whether Craig had heard them, especially in view of the increasing noise and confusion at the scene. Nevertheless, for the purposes of the present article, it will be assumed that they were in fact heard by Craig. If he did not do so, strictly the case was an instance of attempted incitement only. ${ }^{48}$

What, then, is the correct approach to the interpretation of ambiguous language in situations, such as the Craig and Bentley case? Some approaches can be ruled out as being contrary to principle or as being entirely inappropriate for use in this area of the law.

There may be a temptation, for instance, to adopt an ex post facto interpretation of the words in question. The episode culminated in murder, the argument would run, so the words are to be understood as having been an incitement to commit that very crime. This would be wrong as a matter of principle. Whatever the applicable test, it is to be applied to the words themselves regardless of their consequences (whether actual or supposed). ${ }^{49}$

Alternatively, it might seem appropriate to seek assistance from a field of law where the role played by language is of central importance; namely, defamation. The test that is deployed there-sometimes referred to as the "single meaning rule" - is: "What would an ordinary and reasonable person infer as the natural and ordinary meaning of the words?" It has been described in this way: "What matters is what the [judge] thinks is the one and only meaning that the readers...should have collectively understood..."50 This approach might well be suitable for an area of the law that is concerned with potential damage to the plaintiff's reputation at large. It is not so where criminal liability is an issue and where matters of the intention of the speaker and the foreseeable effects on the person(s) addressed are of central importance. However, it does possess the advantage of being a test

\footnotetext{
${ }^{46}$ In regard to the last point, there is an interesting comparison to be drawn here with provocation (or, as it is now known, "loss of control"). Where this is pleaded to a charge of murder, the time that elapsed between the trigger event and the homicide is one amongst several factors that the jury is directed to take into account since, with the passage of time, the anger of the accused at the act of provocation might have abated.

47 It is ironic that Bentley's counsel was put to arguing at length about the intent behind words that his client denied having said.

48 There was clear authority that such a doubly inchoate crime was known to English law. In $R v$. Banks (1871-74) 12 Cox C.C. 393, a letter containing an incitement to commit a crime was intercepted before it could reach the intended addressee. The jury was held entitled on the facts to return a verdict of attempting to incite. As with all attempt situations, the actions of the accused must be more than merely preparatory: $R$ v. Rowley [1991] 4 All E.R. 649. Compare the approach under the U.S. Model Penal Code (American Law Institute, 1962) section 5.02: "It is immaterial...that the actor fails to communicate with the person he solicits to commit a crime if his conduct was designed to effect such communication.".

49 The critical words could not be regarded, even on the malevolent interpretation, as an unequivocal incitement to commit murder. They could equally be interpreted as an exhortation to inflict serious injury. This, however, would not affect the outcome of the case since the mens rea of murder includes intention to commit grievous bodily harm.

50 Ajinomoto Sweeteners Europe SAS v. Asda Stores Ltd. [2009] EWHC 1717 (QB); [2009] 3 W.L.R. 1149, at pp. 1153-61.
} 
that would not be embroiled in situations of actual or potential mismatch between the intention of the speaker and the way in which his words were understood by the addressee.

In the absence of a single, overarching test such as this, there are two focal points to be explored. How were the words "Let him have it" intended by Bentley? In what sense were they understood by Craig? The court concentrated exclusively on the first question. That no consideration was given to the second question was not surprising since Craig denied having heard the words. But, let us assume, instead, that he had admitted to having heard them. There would then be several possibilities running along the intent-effect axis.

It could be that the crucial words were both intended and understood in the malevolent sense (in which case, it would be a clear instance of incitement). Or, that the words were both uttered and understood in the benign sense (when, without question, there would be no liability). More problematic would be mismatch situations. The first would be where there was a malevolent intent behind the words but they were understood in the benign sense; the second where there was a benign intent but the words were received in a malevolent sense. The former could be categorised simply as an attempted incitement. As regards the latter, it could be said that the accused would be properly convicted if he knowingly took an unreasonable risk that his words would be understood as an encouragement to commit crime. On that basis, Bentley, even if not intending to incite Craig to commit murder, was reckless in choosing words that could readily be interpreted as bearing that meaning. ${ }^{51}$ Indeed, an overriding emphasis on the way in which words are received by the addressee(s) is not unknown. It is to be found in section 1 of the Terrorism Act 2006, the cutting edge of which is "a statement that is likely to be understood by some or all of the members of the public to which it is published" as an encouragement of terrorism.

Imposing criminal liability for the uttering of words is quite different from the infliction of such liability for the use of standard tools of crime. The consequences of using weapons such as guns and knives are closely determined by fixed features of the world such as the laws of ballistics and human vulnerability. ${ }^{52}$ By contrast, words, even if they have a settled core of meaning, will characteristically be understood in different ways, and evoke different responses from different people. Therefore, it might be considered just that-in contrast to the views noted in Sect. 1.4, above-the accused is held liable if he consciously assumed an unreasonable risk that his words would be understood as an incitement to commit crime.

\subsection{Oblique Incitement}

There has been extensive consideration of the moral responsibility of persons who perform acts with an oblique (or, as it is more often described, "indirect") intention. Typical instances considered in this context are those where medical procedures are carried out on a pregnant woman leading inevitably to the destruction of the foetus, or where military action is taken in wartime against combatants that carries a high probability of civilian casualties. In neither of these situations is harm to the child or the civilians intended, but it is foreseen as the consequence of carrying out the medical procedures and the military action, respectively. These are the nearest analogous situations to the problem that concerns us here. That is where words spoken by A to B cannot be literally interpreted, in any sense, as a call to B to commit a crime, yet the surrounding circumstances are such that the

\footnotetext{
51 I am grateful to Antony Duff for helping me to clarify the mismatch situations.

52 See D.P.P. v. Smith [1961] A.C. 290 as an example of the interplay of these factors in a situation where the accused did not intend, in the narrow sense, to kill the accused.
} 
perpetration of a crime by B is a reasonably foreseeable consequence of the words spoken. Two hypothetical examples may be given.

The first of these has already attracted some academic attention. It is the murder committed by Othello, in Shakespeare's play, of his wife Desdemona. Othello is goaded into this by the doubts as to her fidelity maliciously planted by Iago. Sir James Stephen believed that the only basis upon which Iago could have been convicted as an accessory before the fact to the murder was the advice that he gave to Othello: "Do it not with poison; strangle her in her bed, even the bed she hath contaminated." 53 The situation becomes, with these words, a straightforward case of incitement. The more interesting issue would be the question of Iago's liability in their absence. Certainly, sexual infidelity that culminates in the killing of the unfaithful person by the wronged partner has formed a standard situation where, on account of provocation, a charge of murder could be reduced to a conviction for manslaughter. ${ }^{54}$ Here, however, Desdemona (as Iago knows) is innocent of adultery; his motive in telling the falsehood is to foment marital discord (admittedly, of an indeterminate extent). Do these factors convert the case into one of inciting Othello to commit a crime against Desdemona? An obstacle to adopting that approach would be that, in view of the absence of explicit words of incitement, it would be difficult to determine exactly which crime that should be.

The second example is drawn from Mill's essay, On Liberty. The passage, though occasionally mentioned in commentaries on the essay, has received little detailed consideration, least of all from a legal point of view:

No one pretends that actions should be as free as opinions. On the contrary, even opinions lose their immunity when the circumstances in which they are expressed are such as to constitute their expression a positive instigation to some mischievous act. An opinion that corn dealers are starvers of the poor, or that private property is robbery, ought to be unmolested when simply circulated through the press, but may justly incur punishment when delivered orally to an excited mob assembled before the house of a corn dealer, or when handed about among the same mob in the form of a placard. ${ }^{55}$

The first point to be made about this example — one of which it is now easy to lose sight-is that it will have been quite topical. On Liberty was published in 1859 although substantially completed some years earlier. The Corn Laws, the cause of widespread distress in society, had been eventually repealed in the face of fierce opposition in 1846. As regards the content, it is noteworthy that Mill's narrative stops abruptly after the above passage. He does not inform his readers of the reaction of the mob to the dissemination of the opinions in question. Did it perpetrate a violent act on the corn dealer or his property? Or, although initially agitated, did it calm down and disperse? Indeed, even to speak in terms of a "mob" is to ignore the fact that it is simply an aggregation of individuals, the reaction of some of whom may well have differed from that of others.

The sentence "No one pretends that actions should be as free as opinions" is particularly worthy of attention. The most natural reading is that any eruption of violence should have been properly curtailed and punished by the authorities. But that is so obvious a point

\footnotetext{
53 Act IV, scene 1.

54 See now the Coroners and Justice Act 2009, s. 55(6)(c), according to which the fact that "a thing done or said constituted sexual infidelity" is to be disregarded in determining whether a loss of self-control had a "qualifying trigger" for the purposes of the Act. The scenario accords, certainly, with the requirement of "a thing...said"; however, that was not actual sexual infidelity but rather a false allegation of the same.

55 Mill, On Liberty, at p. 119.
} 
that it surely cannot have been what Mill meant. Rather, the word "actions" in this context must be taken as referring to the dissemination of the two provocative opinions in front of the corn dealer's house. In other words, what appear to be instances of speech and nothing more-in oral form in one case, written in the other-become reclassified for this purpose as "actions." ${ }^{56}$ As was the case with Iago in the previous example, the disseminators of the opinions in question were not, in so many words, inciting the use of violence. It was the juxtaposition of the messages and the location in which they were published that rendered such an outcome likely.

How would the criminal law deal with those who circulated the messages in question? The nearest analogous situation in the English reports is $R v$. Burns, ${ }^{57}$ a charge of sedition that arose out of riots at public meetings that were being addressed by the accused. The report, which consists of the direction to the jury by Cave J., reveals that the overriding considerations that the jury was directed to take into account were the motives of the accused: “...if you come to the conclusion that [the accused] were actuated by an honest desire to alleviate the misery of the unemployed...you should not be too swift to mark any hasty or illconsidered expression which they might utter in the excitement of the moment." 58 The point is borne out by an exchange between Cave J. and the Attorney-General, who was leading the prosecution: "Suppose a man were to write a letter to the papers attacking bakers or butchers generally with reference to the high prices of bread or meat" - the judge asked- "and imputing to them that they were a conspiracy to keep up the high prices, would that be a seditious libel...?" That particular example was not fully in point since the dispersed newspaper readership, unlike the mob in Mill's example, would not provide a focus of public disorder. The Attorney-General would not give a definite answer: it would all depend, he said, on the circumstances, especially the motives of the accused. ${ }^{59}$ What would appear to have been a gap in the criminal law's protection of individuals through the doctrine of incitement was, to some extent, repaired by the general law of public order-in this case, the crime of sedition. The question now arises as to whether, with the recent abolition of that offence in English law, ${ }^{60}$ that lacuna has been re-opened.

\section{Responses to Language}

In this section, our attention moves from questions of the meaning, or interpretation, of the message of incitement to the response that the communication arouses in the person or persons addressed. The two matters are not entirely separate. The prime consideration in the likely reaction of the addressee(s) will be the interpretation that the latter will place on the words, rather than the intention with which they were spoken or written, still less the "meaning" of the words in some abstract sense. This is a point that is borne out by the emphasis placed by section 1 of the Terrorism Act 2006 (quoted above) on the way in which a statement is likely to be understood by those to whom it is published.

In principle, irrespective of the legal system, there are two main approaches to the structure of crimes where the actus reus (or equivalent term) consists of uttering words,

\footnotetext{
56 This is perhaps an anticipation of the idea of "speech acts" espoused by John Austin in How to Do Things with Words (Oxford 1961).

57 (1886-1890) 16 Cox C.C. 355.

58 Ibid., at p. 363.

59 Ibid., at pp. 360-361.

${ }^{60}$ By the Coroners and Justice Act 2009, s. 73(a).
} 
whether in spoken or written form. The one focuses exclusively on the words, without any regard of the effect that they have or might have on those who are exposed to them. The mere fact of having uttered words of the appropriate type suffices, in itself, to found liability. The clearest example is perjury, committed by a witness giving testimony that he knows to be untruthful. Whether the court believes, or is swayed by, the testimony is irrelevant to the issue of liability. We may call this a "context-independent" crime. The other approach goes further, taking into account the effect (whether actual or surmised) exerted on the recipients of the message. Liability is founded in this case only if the communication has exercised on them a harmful influence as defined by the applicable law. And, of course, it may work its influence only if they have heard or read it. This may be called a "context-dependent" crime. The distinction between the two approaches, though fundamental, has scarcely been noted. It happens to have been captured, though only in passing, in one of the most famous trials of antiquity: that of Socrates in 399 B.C. for corrupting the youth of Athens. At one point in his defence speech Socrates asks his accusers: "...surely we know what kinds of corruption affect the young; so you tell us whether you know of any one who under my influence has fallen from piety into impiety, or from sober into wanton conduct." ${ }^{21}$ The question was this: was Socrates to be condemned simply on the basis of the content of his teachings? Or did his accusers have to establish, in addition, that those teachings had worked an effect that was harmful (harm being judged as being of the type that was contrary to Athenian law) to those who had been exposed to them? The implication behind the quoted passage was that Socrates was arguing, as was to be expected, in favour of the latter characterisation.

To which of these two models of liability does the law of incitement most closely approximate? At common law incitement would appear to have been a context-independent form of crime: the nature of the response of the addressee had no bearing on the issue of the liability of the person who extended the message of encouragement. The position is not so clear under the Serious Crime Act 2007. The key provisions, sections 44 and 45, depend on the doing of an act "capable of encouraging...the commission of an offence." But what does "capable of encouraging" mean? Does it suffice that there is a verbal formula that can readily be interpreted as an instigation to the addressee(s) to commit a crime? Or is there an additional element: that it is capable of doing so only when the proclivities of the addressee(s) are factored into the situation? The report of the Law Commission that led to the 2007 Act is not helpful on the point. It concedes the obvious point that inchoate liability is premised on its enhancing "the prospect of actual harm occurring," 62 while admitting an "area of potential difficulty" if nobody is aware of the act of encouragement. ${ }^{63}$

\section{Incitement and Freedom of Speech}

It remains to consider the question of how the law of incitement may be reconciled with the claims of freedom of speech. From a formal point of view, it might appear that there is no conflict whatsoever. Individuals are free to speak insofar as they are not subject to legal duties to refrain from speaking (particularly, for our purpose, the duty not to incite crime).

\footnotetext{
61 Xenophon, Anabasis Books IV-VIII, Symposium and Apology (Loeb Classical Library, London 1922), p. 499.

62 Inchoate Liability for Assisting and Encouraging Crime, at para. 5.27.

63 Ibid., at para. 5.29.
} 
However, the space that is occupied by those duties may be so extensive as to leave little room for meaningful discourse. Furthermore, it might be thought that speech that encourages the listener(s) to break the law is devoid of moral merit and so undeserving of legal protection. But that is to assume that the law is beyond critical reproach in every particular and that no scope is to be left for civil disobedience. How, then, is an accommodation to be reached? A suitable starting point here is a consideration of the problem in the light of the various rationales of freedom of speech.

Liberty of speech is often valued as a means of searching out the truth on particular matters. However, that can have no application to the present problem because sentences that express commands lack truth conditions; that is, they cannot be true or false. Rather, they can be described only as either having been complied with or as not having secured compliance. The same goes for sentences, typical of situations of incitement, that urge a course of action without necessarily going as far as commanding it.

A more promising line of analysis is to consider the matter in the light of the rationale of freedom of speech that views it as a means of facilitating the efficient working of a democratic system of government. ${ }^{64}$ This holds that, when a range of possible policy choices is available for consideration by the people and subjected to vigorous discussion, there is a greater likelihood that the selection that is made will be the best in the circumstances. The same applies in regard to candidates for electoral office. Among the various types of speech, clearly, this approach attaches the highest importance to speech that is political in content. Other rationales might accord importance to entirely different forms of speech. Political speech, however, might be directed, not to the electoral merits of particular persons or parties, but to the wisdom of individual laws, in particular criminal laws. In that event, it can be seen that a call to repeal or reform the law in question could be interpreted as a claim that the law as it stands has little (if any) claim on the obedience of citizens, and consequently as an incitement to disobey the law in its unreformed state. ${ }^{65}$

Even laws which any civilised society must contain are not immune to challenge in this way, in point of detail at least. There is no more basic legal prohibition than that of homicide. Yet the status of acts of tyrannicide, whether as a moral imperative or as a permissible action, has at times been the subject of vigorous debate. ${ }^{66}$ More provocative still, and infinitely more far-reaching in its practical implications, is the view espoused by some philosophers that there is nothing intrinsically wrong in committing infanticide. ${ }^{67}$ The reason offered is that, from a moral point of view, to kill a neonate is indistinguishable from abortion, and that the prohibition of it can be defended only on the basis of the distressing effect that it might have on others. Could publications that seek to defend tyrannicide and infanticide, therefore, be considered as incitements to commit those forms of killing? Or are they to be treated merely as exhortations to change the law (or, at least, prosecutorial policy) in those same areas? The practical relevance of debates about the legitimacy of tyrannicide or regicide (clearly, they are not necessarily the same) is much reduced from the situation of 100-150 years ago, when plots abounded for the

\footnotetext{
64 This is a perspective particularly associated with the writings of Alexander Meiklejohn: see, for example, note 70 , below.

65 On the other hand, liability still depending on mens rea, it might be difficult to show that the speaker intended his audience to break the law. Moreover, the Serious Crime Act 2007, s. 50, furnishes a defence that it was "reasonable" for the accused to have acted as he did in the circumstances. Of particular value to him will be the importance attached by s. $50(3)(\mathrm{b})$ to the purpose that he had in so acting.

66 See the reference to this dispute in Mill, On Liberty, at p. 75.

67 See, for example, P. Singer, Practical Ethics (Cambridge 1979), pp. 122-126.
} 
assassination of various European monarchs - the prospects of success for which had been increased significantly by technological advances, such as more compact explosives and smaller guns.

The law on freedom of speech must tread a delicate line between safeguarding open discussion of the legitimacy of maintaining particular prohibitions, on the one hand, and penalising instigations to commit the very same transgressions, on the other. Case law on the First Amendment has sought, in this way, to differentiate between "advocacy" (which is constitutionally protected) and "incitement" (which may legitimately be penalised). In a confusing double use of the former term, the U.S. Supreme Court explained it as being "the distinction between advocacy of abstract doctrine and advocacy directed at promoting unlawful action." 68 The viability of the distinction has been criticised on two grounds. First, there may not, in the end, be a distinction of substance between the two since effective advocacy might amount to an incitement. As Holmes J. expressed it: "The only difference between the expression of an opinion and an incitement in the narrower sense is the speaker's enthusiasm for the result." ${ }^{69}$ Second, even if the distinction is intelligible, the Founding Fathers of the Constitution were practical men who did not intend to confine the protection of the First Amendment to abstract discussions of an academic sort. ${ }^{70}$ The difficulty with the first objection is that it appears to make the advocacy/incitement distinction turn, after the event, on the impact made by the written or spoken words: if any addressee acts in the way that is urged by the speaker, the words amount to incitement; if not, they constitute advocacy. This is certainly at variance with the approach of English law on the subject.

Furthermore, there is surely a third possibility: that of speech that is more than abstract discussion, but less than a call to break the law. The speech would be a call to action, but the action in point would be the repeal of the law in question. More pertinently, the very frequency or infrequency with which the issue is raised as a practical matter may incline the analysis in the direction of one or the other of the advocacy/incitement polarities. The merciful infrequency with which the question is presented as to whether assassination is a proper response to the actions of a tyrant will tend to place that issue towards the advocacy end of the spectrum.

English law lacks does not formally distinguish between advocacy and incitement. This is not surprising in view of the historical absence of a written guarantee of freedom of speech. Yet it is possible to find arguments that, though not explicitly cast in these terms, reflect the substance of that distinction. In $R v$. Bowman ${ }^{71}$ a prosecution under the Incitement to Mutiny Act 1797, the defence unsuccessfully argued that the publication was a general comment on the use of military force to suppress industrial riots rather than a specific attempt to persuade troops to disobey their officers. Beyond that, it is possible to find cases where the antithesis between advocacy and incitement is intertwined with several of the themes of the present article.

The case of $R v$. Diamond $d^{72}$ furnishes a good example. The defendant was charged with contravening section 4 of the Offences against the Person Act 1861 in soliciting "persons unknown" to murder the Viceroy of Ireland, Lord French. The alleged incitement took the

\footnotetext{
68 Yates v. U.S. 354 U.S. 298 (1957).

69 Gitlow v. New York 268 U.S. 652 (1925), at p. 673.

70 A. Meiklejohn, Political Freedom: The Constitutional Powers of the People (Oxford 1965), pp. 41-42.

71 (1912) 76 J.P. 271.

72 (1920) 84 J.P. 211.
} 
form of an article in a newspaper, the London Catholic Herald, entitled "Killing no Murder." The tone of the article was decidedly abstract. It drew by way of justification on historical examples of the assassination of figures of oppression, from that of Julius Caesar to the assassination in 1914 of the Archduke Franz Ferdinand. There was no mention of anyone involved in the British administration of Ireland. The only connection with Lord French was that there had been an (unsuccessful) attempt on his life a week prior to the publication of the article. There was not even an Irish edition of the newspaper, though, like other London newspapers, some copies would doubtless have found their way to Ireland. Coleridge J.'s direction to the jury included the following points. It was not necessary that any person be proved to have been persuaded to act on the message conveyed in the newspaper. It was a matter for the jury alone to decide on the "meaning of the language" used in the piece (he did not go on to elucidate what he meant by "meaning"). And, finally, it fell to the jury to decide whether, in the circumstances, the expression of an abstract opinion had become an encouragement to commit crime.

The Campbell prosecution of 1924 is best known as having led to the fall of the first Labour government after only a few months in office. The centrepiece was an issue of the Workers' Weekly, a Communist publication that called on members of the armed forces to let it be known that "neither in a class war nor in a military war will you turn your guns on your fellow workers." Campbell, as acting editor, was charged under the Incitement to Mutiny Act 1797. The case did not proceed to trial, the circumstances under which the prosecution was withdrawn giving rise to serious constitutional issues. Had it done so, it would have been ripe for analysis in accordance with the principal themes of the present article. As a matter of interpretation, the article could only have been referring to war with Soviet Russia or the deployment of troops in industrial disputes. There was no immediate prospect of troops being deployed in these ways, ${ }^{73}$ the publication being by way of general appeal only. Apart from the issue of interpretation, therefore, the article would have been categorised as an occasion of advocacy rather than of incitement. Finally, an argument could have been constructed that would have been based on the concept of contextdependency, emphasising the paucity of Communist members of the armed forces.

However, once an idea enters general currency, it is capable of exerting an influence, whether for good or ill, in circumstances that were not fully envisaged at the time of its original publication. Holmes J. once famously remarked: "Every idea is an incitement. It offers itself for belief, and, if believed, it is acted on unless some other belief outweighs it, or some failure of energy stifles the movement at its birth." 74 Consider this in the light of the motion passed by the Oxford Union in February 1933: "This House will in no circumstances fight for its King and country." Had the same message been specifically directed at members of the armed forces, it could have amounted to an offence under section 1 of the Incitement to Disaffection Act 1934, since the implication would have been: "This House will in no circumstances fight...nor should you." However, published (as it was) without being so directed, the stated refusal to bear arms irrespective of the political situation possessed only the abstract quality of the student debating society in which it was aired.

The earliest guarantees of freedom of speech, not surprisingly, did not address the question of reconciling those guarantees with the law of incitement. Accumulation of experience, however, has led the drafters of modern declarations of the guarantee to attempt some accommodation between the two. For example, while Article 19(1) of the

73 This is affirmed by A.J.P. Taylor, English History 1914-1945 (Oxford 1965), p. 225.

74 Gitlow v. New York 268 U.S. 652 (1925). 
Constitution of India 1949 assures to all its citizens the right to "freedom of speech and expression," Article 19(2) goes on to state that nothing in that provision shall prevent the enactment of legislation "in so far as such law imposes reasonable restrictions on the exercise of the right in the interests of...or in relation to contempt of court, defamation or incitement to an offence." Clearly, the protection afforded by Article 19(1) would be substantially diminished by permitting exceptions to it merely in the form of "restrictions" that did nothing more than relate, in pith and substance, to "incitement to an offence" (or contempt of court or defamation). A more substantial limitation was needed to limit the scope of any restrictions - a burden that is borne here entirely by the further requirement that any restriction be "reasonable." In contrast, the Constitution of South Africa 1996, section 16(2), permits of a wider scope for freedom of speech since the only relevant qualification is that it does not extend to "incitement to imminent violence," or to "advocacy of hatred" that is based on certain attributes (e.g. gender, religion) and which, moreover, "constitutes incitement to cause harm."

\section{Conclusion}

Incitement has traditionally been relegated to the margins in criminal law textbooks. Several developments, however, have rendered it of ever-expanding importance. Modern ease of communication, both nationally and internationally, has vastly increased the potential audience for messages of incitement and made ever-shorter the period in which exposure to them may evoke a criminal response. Of greater importance is the fact that two of the scourges of the modern world-genocide and terrorism-have been met by legal responses in which the role played by incitement has been recognised as being of special significance. This article has sought to illuminate some of the hitherto unexplored issues that are likely to be raised by a more frequent resort to the law of incitement.

Acknowledgements Thanks are due to Philip Handler for clarifying historical points and to Antony Duff, Hannah Quirk, Martin Wasik, and the anonymous referees for their criticisms of earlier drafts. The usual disclaimers apply.

Open Access This article is distributed under the terms of the Creative Commons Attribution 4.0 International License (http://creativecommons.org/licenses/by/4.0/), which permits unrestricted use, distribution, and reproduction in any medium, provided you give appropriate credit to the original author(s) and the source, provide a link to the Creative Commons license, and indicate if changes were made. 